may be that a primary attack of pellagra only follows a long-continued deficiency in "B.V.P." such as these troops never experienced in the field, while the onset of wasting dysentery was so promptly met by rest in bed and appropriate milk diet that the malassimilation resulting was met from the outset by so complete a conservation of energy that relative insufflciency was not established. It must, however, be frankly admitted that this explanation is not convincing.

Is the deficiency factor only a contributory factor to a determining cause yet to find? If so, the suggestion that the latter is to be sought in an helminthic infection such as ascaris is equally difficult of acceptance, because the apparently healthy Turks were equally infected with the pellagrous, and the immune Indian troops were heavily infested by ascaris, if my recollection serves $m e$ well with regard to the findings of Major F. W. Stewart, I.M.S.

I am, Sir, yours faithfully,

P. S. LELEAN,

Lieutenant-Colonel, R.A.M.C.; Professor of Hygiene. R.A.M. College, July 11th, 1920 .

\section{MEDICAL EXPERIENCES IN MACEDONIA AND} THE CAUCASUS.

To the Editor of THE LANCET.

SIR,-Dr. Arthur Phear, in a lecture on his experiences in the East, which was given before the Royal Society of Medicine and published in THE LANCET of July 10th, refers to my observations on quinine which appeared in the Journal of Hygiene in October, 1919. Dr. Phear has given a condensed account of his experiences of various diseases, and a still more condensed abstract of my observations; in fact, he omits the essential points, but a relatively lengthy criticism follows. I showed that when quinine is injected intramuscularly, in concentrated or dilute solutions, it is absorbed with remarkable rapidity. At the end of two hours from the time of the injection the majority of the quinine has been removed. This was found to be the case in man, and in mules which were inoculated experimentally. This fact, which is of very great importance, is not referred to by Dr. Phear. The injection of any preparation of quinine into muscles, or subcutaneously, produces tissue necrosis which may be extensive. Animal experiments have shown that disasters will occur if the injections are not made correctly, and the complications which arise are, as would be expected, exactly those which are met with in the human subject. In my paper I have given a list of the complications which did occur among men injected intramuscularly with quinine, and some of these complications were of a very serious nature. Dr. Phear, apart from some cases of dysentery, never met with any serious complication. There are a very large number of others who will entirely agree with him, but, in my opinion, if it is fully recognised that serious troubles may arise unless the dangers, and how to avoid them, are fully understood, then quinine injections will not be regarded with apprehension. The remarkable fact that many thousands of injections of quinine were given during the war alone without mishap is great testimony to the recuperative power of the tissues. A distinguished member of the medical profession wrote to me in reference to $\mathrm{my}$ paper on quinine as follows: "No one should be allowed to inject toxic substances such as quinine into the tissues of his fellow creatures until he is fully acquainted with the dangers, which should be learnt by animal experiment.' I am, Sir, yours faithfully,

London, July 12th, 1920. LEONARD S. DUDGEON.

\section{PHYSICAL ELEMENT IN PSYCHONEUROSES.} To the Editor of THE LANCET.

SIR,-I, like Dr. Judson Bury, "have been much impressed by the frequency with which relapses have occurred in cases which had been discharged from Maghull, Seale Hayne, and other neurological hospitals as either cured or improved," and I am glad to find that the medical profession is beginning to appreciate the folly of imaginin that it is possible permanently to cure psychoneuroses in a few minutes by suggestion, persuasion, \&c. It is possible, and easy, it is also wise, to remove certain troublesome symptoms in this way but it is not possible thus to replace suddenly the lost "ergogen" in the brain cells or to prevent relapse. All ysterical patients become also neurasthenic in time, unless their improvement by psychotherapy is confirmed into cure by country work and convalescence. At one period I could have sent away at a time 500 to 600 sufferers from war neuroses separately (and this is mportant) to light work in the gardens of England, Scotland, and Ireland; but the Government departments concerned were hoodwinked by the wonder-workers, the ten-minute curers, who misled themselves by not following up their cases, and dazzled the mental vision of the authorities by the evanescent brilliance of their immediate results.

Now that the Country Host Scheme has been taken over by the Red Cross and that private enthusiasm has diminished, I fear there is much difficulty in finding hosts, but I am still seeing very many neurasthenics who urgently need non-institutional convalescence and who probably will not recover permanently till they get it. Could not our country confrères persuade landed proprietors and others in their district to act as "hosts" to single neurasthenics, who would live with the gardeners for two or three months and work with the latter, not for pay but by way of treatment?

Any "host" willing to receive such a patient shonld communicate with the County Director, Red Cross (Country Host Scheme), 27, Grosvenor-place, London, S.W. 1. I am, Sir, yours faithfully,

South Eaton-place, S.W., July 9th, 1920. THOMAS LUMSDEN.

\section{THE TEACHING OF OBSTETRICS.} To the Eaitor of THE LANCET.

SIR,-In a leading article in THE LANCET for July 3rd it is stated that-

"We believe it is only the Universities of Oxford and Cambridge which require that the student shall actually receive practical instruction in lying-in wards before presenting himself for his examination in midwifery."

In the Calendar of the University of Leeds, 1919-20 p. 409 et seq., the regulations for candidates read thus:-

Hospital work-In Obstetrics (a) of having attended during not less than one month the indoor practice of a Luing-in Hospital or the Lying-in Wards of a general hospital approved by the University and (b) having personally conducted not less than twenty cases of labour, \&c.

For many years this rule has been complied with. Each student attends for one month and receives practical instruction at the Leeds Maternity Hospital (70 beds) before being allowed to attend cases in the district. I may add that arrangements are now being made to carry out the suggestions of the General Medical Council in a more complete manner than formerly possible. It may not be without interest to state that candidates for the final examination are required to undergo a clinical examination in gynæco. logy, and I think that this university was the first to carry this idea out some 12 or 15 years ago.

I am, Sir, yours faithfully,

E. OCTAVIUS CROFT,

University of Leeds, July 8th, 1920. Professor of Obstetrics.

\section{THE- BIOCHEMISTRY OF MICRO-ORGANISMS}

\section{To the Editor of THE LANCET.}

SIR,-The short report, appearing in THE LANCET of June 26th, of a paper on detoxicated vaccines which I read at the Brussels Congress (Royal Institute of Public Health) in May was misleading, and I should like to give a short résumé of my work, during the past two years, on the detoxication of vaccines, which has largely developed into a study on the biochemistry of micro-organisms. Whilst researching on the bio chemical composition of germs I have carried out at the same time a parallel series of investigations on various tissues of animals and certain plants.

All bacteria are closely related in their biochemical composition to animal tissues, and consist largely of 